\title{
Effect of Feeding or Intubation of Tryptophan or Methionine and Threonine on Hepatic Polysome Profiles in Rats under Meal-feeding or Fasting Conditions
}

\author{
Hidehiko Yokogoshi and Akira YoshidA \\ Department of Agricultural Chemistry, Nagoya University, \\ Nagoya 464, Japan \\ Received August 11, 1982
}

\begin{abstract}
Under meal-feeding conditions, supplementary tryptophan in a protein-free diet did not aggregate hepatic ribosomes, while the supplementation of methionine and threonine to the protein-free diet aggregated the ribosomes as compared with that in rats fed the protein-free diet. Under long-fasting conditions, this effect of methionine and threonine on polysomal aggregation disappeared. Intubation of tryptophan caused the aggregation of hepatic ribosomes, especially in fasted rats, and this aggregation with tryptophan disappeared on simultaneous administration of glucose, and then serum glucocorticoid was significantly enhanced but serum insulin was not changed. With single addition of tryptophan, methionine, threonine or leucine, serum glucocorticoid was enhanced in all groups but polysome aggregation was observed with only tryptophan addition. These results suggested that, although the intubation of tryptophan or another amino acid to long-fasted rats induced the increase of serum glucocorticoid which causes the degradation of extrahepatic tissue proteins, tryptophan might be the first limiting amino acid of endogenous amino acids in fasting conditions and consequently enhances the hepatic ribosome aggregation. In meal-feeding or ad libitum feeding of a protein-free diet, methionine and threonine might be the more limiting amino acids.
\end{abstract}

Extensive observations have been made on the effect of tryptophan-deficiency on hepatic protein synthesis, specifically on polysomal function. ${ }^{1 \sim 5)}$ The single administration of tryptophan or other amino acids to mice and rats has been also reported to promote liver polysome aggregation. ${ }^{6 \sim 13)}$ However, in those experiments, starved animals and an intubation technique of administration of an amino acid were usually used. In our previous work, ${ }^{14)}$ when rats were meal-fed the proteinfree diet supplemented with tryptophan, the polysome status was not changed as compared with that in rats meal-fed the protein-free diet.

In this work, we reinvestigated whether tryptophan participates in a unique action for protein synthesis or not and the effect of methionine and threonine on hepatic polysome profiles of meal-fed or starved rats by the method of feeding or intubation.

\section{MATERIALS AND METHODS}

Animals and diets. Young female rats of the Wistar strain weighing about 100 to $150 \mathrm{~g}$ were used, six rats per group, and fed a commercial stock diet* for 3 days to allow them to adjust to the new environment. They were then offered an adequate purified diet $(25 \%$ casein-sucrose diet) for a 5-hour period (10:00 to 15:00 hours) once a day for 1 week until they had adapted to the new feeding regimen. The rats were then meal-fed a protein-free diet for 5 days except in experiment 1 which involved ad libitum feeding. The composition of the protein-free diet was by percentage: salt mixture, ${ }^{15)} 5$; vitamin mixture in lactose, ${ }^{15}$ ) 0.85; choline-chloride, 0.15 ; corn oil, 5 ; and sucrose, 89 . Retinylpalmitate, ergocalciferol and DL- $\alpha$-tocopherylacetate were included at concentrations of $600 \mathrm{IU}, 1.5$ $\mu \mathrm{g}$ and $10 \mathrm{mg}$ per $100 \mathrm{~g}$ of diet, respectively. Only $\mathrm{L}-$ amino acids were used. Diets were mixed with the same weight of $3 \%$ agar solution to make agar-gel diets. The room temperature was kept at $24^{\circ}$ with 12-hour cycles of light and dark. All rats were individually housed, provided feed and weighed daily during the experimental period.

Experiment 1. The effect of supplementary tryptophan in a protein-free diet on polysome profiles in liver was

* CE-2, Japan Clea Co. Ltd., Tokyo. 
investigated. Rats were, ad libitum, fed a protein-free diet or protein-free diet supplemented with $0.3 \%$ of tryptophan for 10 days. At the end of the feeding period, rats were killed by decapitation and the liver was removed to determine the polysome profiles. ${ }^{16)}$

Experiment 2. The changes in the hepatic polysome profiles of rats meal-fed a protein-free diet supplemented with tryptophan for 1 day were investigated. Rats were meal-fed a protein-free diet for 5 days and, on the next day, were meal-fed the protein-free diet or protein-free diet supplemented with $0.09 \%$ or $0.3 \%$ of tryptophan for only 5 hours. Then after meal-feeding the diets at 13:00 hours, rats were killed by decapitation and the liver was removed to determine the polysome profiles. ${ }^{16)}$

Experiment 3. The changes in the hepatic polysome profiles of rats meal-fed a protein-free diet supplemented with various levels of tryptophan for 1 or 2 days were investigated. Thirty-six female rats were meal-fed a protein-free diet for 5 days. On the next day, rats were fed the test diets for 5 hours only once for 1 day or twice for 2 days, and were killed by decapitation immediately after feeding. L-Tryptophan was supplemented to the proteinfree diet at the levels of $0.1,0.2,0.3,0.5$ or $1.0 \%$ of diet, respectively. Livers were removed immediately and weighed. Liver homogenate was used to obtain polysome profiles as described in our previous paper. ${ }^{16)}$

Experiment 4. The changes in the hepatic polysome profiles of starved rats tube-fed only tryptophan or methionine and threonine or meal-fed a protein-free diet supplemented with tryptophan or methionine and threonine were investigated. Before beginning this experiment, animals were fasted overnight but had free access to water. Though the diet was not available from 18:00 hours to $18: 00$ hours the next day, the fasting period was perhaps about 35 hours because the feeding time of rats was almost always at night. The following morning, the animals were divided into seven groups of six rats each. Rats in group 1 were fasted and killed at 18:00 hours. Animals in groups 2 to 4 were given by intubation distilled water, $0.15 \mathrm{mmol} \mathrm{L}$ tryptophan per $100 \mathrm{~g}$ body weight $(30 \mathrm{mg}$ in $3 \mathrm{ml}$ water per $100 \mathrm{~g}$ body weight) or $0.15 \mathrm{mmol} \mathrm{L}$-methionine and 0.15 mmol L-threonine per $100 \mathrm{~g}$ body weight $(22.4 \mathrm{mg}$ or $17.9 \mathrm{mg}$ in $3 \mathrm{ml}$ water per $100 \mathrm{~g}$ body weight, respectively), by stomach tube at 18:00 hours and killed by decapitation 1 hour after intubation at 19:00 hours. Rats in groups 5 to 7 were fed a protein-free or protein-free diet supplemented with $1.2 \%$ of tryptophan or $0.9 \%$ of methionine and $0.72 \%$ of threonine at 18:00 hours (if rats were fed $5 \mathrm{~g}$ of test diet, the content of each amino acid fed was the same as the intake in the case of intubation) and killed by decapitation 3 hours after feeding at $21: 00$ hours. Livers were removed to determine the polysome profiles. ${ }^{16)}$

Experiment 5. The effects of glucose, tryptophan or methionine and threonine on hepatic polysome profiles in starved or meal-fed rats were investigated. Fifty-female rats were meal-fed a $25 \%$ casein diet for a 5 -hour period (10:00 to $15: 00$ hours) once a day for two weeks. Trained rats in meal-feeding of groups 1 to 4 were given by intubation distilled water, $0.15 \mathrm{mmol}$ L-tryptophan per $100 \mathrm{~g}$ body weight, $0.15 \mathrm{mmol} \mathrm{L}$-tryptophan and glucose ( $2.3 \mathrm{~g}$ in $3 \mathrm{ml}$ water per $100 \mathrm{~g}$ body weight) or $0.15 \mathrm{mmol} \mathrm{L}-$ methionine and $0.15 \mathrm{mmol} \mathrm{L}$-threonine per $100 \mathrm{~g}$ body weight, by stomach tube at 10:00 hours and killed by decapitation 1 hour after intubation at 11:00 hours. Trained rats in meal-feeding of groups 5 to 7 were mealfed the protein-free diet, and the protein-free diet supplemented with tryptophan or methionine and threonine, respectively. Then the levels of supplemented amino acids were the same as those of the intubated amino acids (same conditions as in experiment 4). On the other hand, in groups 8 to 14, trained rats in meal-feeding were fasted for about 43 hours and then examined by the same procedure as for groups 1 to 7 .

Experiment 6. The effects of tryptophan and/or glucose on insulin or glucocorticoid in serum and hepatic polysome profiles in starved rats were investigated. Twentyfour female rats were meal-fed a $25 \%$ casein diet for a 5 hour period once a day for two weeks. Trained rats were divided into four groups and starved for 48 hours. Animals in groups 1 to 4 were given by intubation distilled water, glucose ( $2.3 \mathrm{~g}$ in $3 \mathrm{ml}$ water per $100 \mathrm{~g}$ body weight), $0.15 \mathrm{mmol} \mathrm{L}$-tryptophan or glucose and tryptophan, by stomach tube at 9:00 hours and sacrificed at 10:00 hours. Serum insulin was determined with a radioimmunoassay kit purchased from Dinabot. Co., Tokyo, Japan. Serum glucocorticoid was determined by the method of Kitabchi et al. ${ }^{17)}$

Experiment 7. The effects of some amino acidintubation on hepatic polysome profiles and serum glucocorticoid in starved rats were investigated. Forty-two female rats were divided into seven groups and starved for 48 hours. Then animals in groups 1 to 5 were given by intubation distilled water, $0.15 \mathrm{mmol} \mathrm{L}$-tryptophan, 0.15 mmol L-methionine, $0.15 \mathrm{mmol} \mathrm{L}$-threonine and 0.15 mmol L-leucine, respectively, and killed two hours after intubation. Rats in groups 6 and 7 were previously injected with insulin $(1 \mathrm{U} / 100 \mathrm{~g}$ body weight) subcutaneously two hours before intubation and killed two hours after intubation of distilled water or $0.15 \mathrm{mmol} \mathrm{L}$-tryptophan. Serum glucocorticoid ${ }^{17)}$ and hepatic polysome profiles ${ }^{16)}$ were also determined.

Statistical evaluations. The statistical significance of differences between values were analyzed by Duncan's multiple range test. ${ }^{18)}$

\section{RESULTS}

Effects of supplementation of tryptophan to a protein-free diet on hepatic polysome profiles (experiments 1 to 3 )

When rats were fed a protein-free diet supplemented with tryptophan for 10 days or only 
Table I. Changes in Polysome Profiles of Rats Fed a Protein-free (PF) or Protein-freE DiET SuPPlEMENTED WITH TRYPTOPHAN For 10 DAYS (ad libitum, EXPERIMENT 1) OR FOR A 5-HOUR PERIOD ONLY ONCE (MEAL-FEEDING, EXPERIMENT 2)

\begin{tabular}{lccc}
\hline Diet & $\begin{array}{c}\text { Initial body } \\
\text { weight } \\
(\mathrm{g})\end{array}$ & $\begin{array}{c}\text { Liver } \\
\text { weight } \\
(\mathrm{g})\end{array}$ & $\begin{array}{c}\text { Monomer-dimers per } \\
\text { total ribosomes } \\
(\%)\end{array}$ \\
\hline Experiment 1 & & & $58.1 \pm 0.2^{2}$ \\
PF & $108.7 \pm 2.5^{1}$ & $3.27 \pm 0.04$ & $62.5 \pm 1.4$ \\
PF $+0.3 \%$ tryptophan & $110.0 \pm 1.2$ & $3.13 \pm 0.08$ & $55.1 \pm 0.9$ \\
Experiment 2 & & & $54.9 \pm 0.9$ \\
PF & $72.9 \pm 1.7$ & $2.50 \pm 0.07$ & $49.7 \pm 0.5$ \\
PF $+0.09 \%$ tryptophan & $74.3 \pm 2.8$ & $2.58 \pm 0.12$ & $50.9 \pm 1.2$ \\
PF & $95.0 \pm 3.6$ & $3.42 \pm 0.16$ & $3.19 \pm 0.07$ \\
PF $+0.3 \%$ tryptophan & $101.5 \pm 0.8$ & & \\
\hline
\end{tabular}

1 Means \pm S.E.M. of six rats per group.

2 Data were based on single analysis of each of three pooled samples of two rats each.

Table II. Changes in Polysome Profiles of Rats Meal-fed a Protein-free Diets (PF) SuPPLEMENTED WITH VARIOUS LEVELS OF TRYPTOPHAN FOR A 5-Hour Period for 1 Or 2 DAys (EXPERIMENT 3)

\begin{tabular}{lccc}
\hline Diet & $\begin{array}{c}\text { Initial body } \\
\text { weight } \\
(\mathrm{g})\end{array}$ & $\begin{array}{c}\text { Liver } \\
\text { weight } \\
(\mathrm{g})\end{array}$ & $\begin{array}{c}\text { Monomer-dimers for } \\
\text { total ribosomes } \\
(\%)\end{array}$ \\
\hline For 1 day & & & $43.3 \pm 0.6^{2}$ \\
PF & $126.4 \pm 3.2^{1}$ & $3.92 \pm 0.11$ & $45.0 \pm 0.7$ \\
PF $+0.1 \%$ tryptophan & $126.7 \pm 2.0$ & $4.07 \pm 0.11$ & $45.4 \pm 1.1$ \\
PF $+0.2 \%$ tryptophan & $128.0 \pm 2.9$ & $4.11 \pm 0.10$ & $46.0 \pm 0.5$ \\
PF $+0.3 \%$ tryptophan & $128.2 \pm 2.7$ & $3.96 \pm 0.12$ & $44.5 \pm 0.4$ \\
PF $+0.5 \%$ tryptophan & $127.8 \pm 2.4$ & $3.69 \pm 0.07$ & $45.2 \pm 0.5$ \\
PF $+1.0 \%$ tryptophan & $127.8 \pm 2.2$ & $3.98 \pm 0.05$ & $45.8 \pm 0.5$ \\
For days & & & $45.2 \pm 0.5$ \\
PF & $114.3 \pm 5.8$ & $3.56 \pm 0.23$ & $48.1 \pm 1.9$ \\
PF $+0.1 \%$ tryptophan & $112.3 \pm 5.3$ & $3.57 \pm 0.20$ & $45.6 \pm 0.3$ \\
PF $+0.2 \%$ tryptophan & $113.8 \pm 5.2$ & $3.33 \pm 0.09$ & $47.3 \pm 0.9$ \\
PF $+0.3 \%$ tryptophan & $115.5 \pm 4.6$ & $3.55 \pm 0.11$ & $44.7 \pm 0.5$ \\
PF $+0.5 \%$ tryptophan & $113.9 \pm 3.9$ & $3.73 \pm 0.15$ & $3.55 \pm 0.12$ \\
\hline
\end{tabular}

1 Means \pm S.E.M. of six rats per group.

2 Data were based on single analysis of each of three pooled samples of two rats each.

5 hours, the populations of hepatic polysomes were not changed compared with those of rats fed the protein-free diet (Table I). Furthermore, when rats were fed the proteinfree diet supplemented with various levels of tryptophan for 1 or 2 days, the aggregation of hepatic ribosomes was not observed (Table II).
Effects of feeding or intubation of tryptophan or methionine and threonine on hepatic polysome profiles of slightly or heavily starved rats (experiments 4 and 5)

Polysome status values were a little lower than those in experiments 1 to 3 . This difference was also observed in a preliminary experiment,* when rats were under mild fasting

\footnotetext{
* H. Yokogoshi and A. Yoshida (1981), unpublished observations.
} 
Table III. Changes in Hepatic Polysome Profiles of Starved Rats Tube-fed only Tryptophan or Methionine and Threonine or Meal-Fed a Protein-free Diet (PF) Supplemented with Tryptophan or Methionine AND THREONINE (EXPERIMENT 4)

\begin{tabular}{|c|c|c|c|c|c|}
\hline Group & Treatment & $\begin{array}{l}\text { Initial body } \\
\text { weight } \\
\text { (g) }\end{array}$ & $\begin{array}{l}\text { Changes in body } \\
\text { weight for } 1 \\
\text { day } \\
\text { (g) }\end{array}$ & $\begin{array}{l}\text { Liver } \\
\text { weight } \\
\text { (g) }\end{array}$ & $\begin{array}{l}\text { Monomer-dimers } \\
\text { per total } \\
\text { ribosomes } \\
(\%)\end{array}$ \\
\hline 1. & None (fasting) ${ }^{1}$ & $130.3 \pm 3.2^{2}$ & $11.0 \pm 1.3$ & $3.57 \pm 0.12$ & $34.6 \pm 0.7^{3 \mathrm{a}}$ \\
\hline 2. & Tube-fed ${ }^{4}$ distilled water & $129.4 \pm 2.6$ & $9.5 \pm 0.7$ & $3.57 \pm 0.10$ & $32.1 \pm 0.5^{\mathrm{b}}$ \\
\hline 3. & Tube-fed ${ }^{4}$ tryptophan $^{5}$ & $128.9 \pm 2.7$ & $9.4 \pm 0.7$ & $3.70 \pm 0.09$ & $31.7 \pm 0.5^{\mathrm{bc}}$ \\
\hline 4. & Tube-fed $^{4}$ methionine $^{6}+$ threonine $^{7}$ & $128.4 \pm 2.4$ & $9.3 \pm 0.5$ & $3.56 \pm 0.14$ & $29.1 \pm 0.2^{\mathrm{c}}$ \\
\hline 5. & Meal-fed ${ }^{8}$ PF & $127.9 \pm 2.4$ & $10.2 \pm 0.4$ & $3.67 \pm 0.10$ & $35.4 \pm 0.3^{\mathrm{a}}$ \\
\hline 6. & Meal-fed ${ }^{8} \mathrm{PF}+1.2 \%$ tryptophan & $127.9 \pm 2.4$ & $10.4 \pm 0.6$ & $3.75 \pm 0.07$ & $35.4 \pm 0.5^{\mathrm{a}}$ \\
\hline 7. & $\begin{aligned} \text { Meal-fed } & \text { PF } \\
+ & 0.9 \% \text { methionine } \\
& +0.72 \% \text { threonine }\end{aligned}$ & $125.7 \pm 3.1$ & $10.8 \pm 0.8$ & $3.64 \pm 0.07$ & $35.9 \pm 0.9^{\mathrm{a}}$ \\
\hline 1 & \multicolumn{5}{|l|}{ Over night fasted animals. } \\
\hline 2 & \multicolumn{5}{|c|}{$\begin{array}{l}\text { Means } \pm \text { S.E.M. of six rats per group. Means within a column not followed by the same superscript letter are } \\
\text { significantly different }(p<0.05) \text {. }\end{array}$} \\
\hline 3 & \multicolumn{5}{|c|}{ Data were based on single analysis of each of three pooled samples of two rats each. } \\
\hline 4 & \multicolumn{5}{|c|}{ Rats were sacrificed 1 hour after tube-feeding. } \\
\hline 5 & \multicolumn{5}{|c|}{$0.15 \mathrm{mmol}$ L-tryptophan per $100 \mathrm{~g}$ body weight. } \\
\hline 6 & \multicolumn{5}{|c|}{$0.15 \mathrm{mmol} \mathrm{L}$-methionine per $100 \mathrm{~g}$ body weight. } \\
\hline 7 & \multicolumn{5}{|c|}{$0.15 \mathrm{mmol} \mathrm{L}$-threonine per $100 \mathrm{~g}$ body weight. } \\
\hline 8 & \multicolumn{5}{|c|}{ Rats were sacrificed 3 hours after meal-feeding. } \\
\hline
\end{tabular}

conditions, ribosomes were a little aggregated due to the supply of amino acids induced by the degradation of extrahepatic tissue proteins. In experiment 4 on slightly starved rats (Table III), the administration of distilled water or tryptophan caused slight aggregation of hepatic ribosomes. The monomer-dimer ratio per total ribosomes of rats intubated with both methionine and threonine was significantly low as compared with that in starved rats. On the other hand, when rats were meal-fed the protein-free diet or the protein-free diet supplemented with tryptophan or both methionine and threonine, the populations of hepatic ribosomes were the same in the three groups. In experiments 5 on meal-fed trained rats (Table IV), intubation of tryptophan, tryptophan and glucose or methionine and threonine caused slight aggregation of hepatic ribosomes as compared with that in rats that received water. While, when rats were meal-fed the protein-free diet supplemented with tryptophan, the population of hepatic polysomes was the same as that in rats meal-fed the protein-free diet. However, the supplementation of methionine and threonine to the protein-free diet caused significant aggregation of hepatic ribosomes. On the other hand, in rats starved for 43 hours previously trained for the meal-feeding schedule, the intubation of only tryptophan caused significant aggregation of hepatic ribosomes, however, intubation of both tryptophan and glucose did not cause significant aggregation. While, when starved rats were fed the protein-free diet or the protein-free diet supplemented with tryptophan or both methionine and threonine, the monomer-dimer values per total ribosomes were the same in these three groups.

Effects of tryptophan and/or glucose on serum glucocorticoid and hepatic polysome profiles in starved rats (experiment 6 )

The monomer-dimer values per total ribosomes of previously starved rats intubated with only tryptophan were significantly decreased as compared with those of rats intubated with glucose or both glucose and 
Table IV. Effects of Glucose, Tryptophan or Methionine and Threonine on Hepatic Polysome Profiles in Starved or Meal-fed Rats (Experiment 5)

\begin{tabular}{|c|c|c|c|c|c|}
\hline Group & Treatment & $\begin{array}{l}\text { Initial body } \\
\text { weight } \\
\text { (g) }\end{array}$ & $\begin{array}{l}\text { Changes in body } \\
\text { weight on } 43- \\
\text { hours-fasting } \\
\text { (g) }\end{array}$ & $\begin{array}{l}\text { Liver } \\
\text { weight } \\
\text { (g) }\end{array}$ & $\begin{array}{c}\text { Monomer-dimers } \\
\text { per total } \\
\text { ribosomes } \\
(\%)\end{array}$ \\
\hline
\end{tabular}

I. Meal-trained rats Intubation $^{1}$

1. Distilled water

2. Tryptophan ${ }^{3}$

3. Tryptophan ${ }^{3}+$ glucose $^{4}$

4. Methionine $^{5}+$ threonine $^{6}$ Feeding $^{7}$
5. Protein-free (PF)
6. $\mathrm{PF}+1.2 \%$ tryptophan
7. $\mathrm{PF}+0.9 \%$ methionine
$96.3 \pm 1.2$
$94.3 \pm 1.2$
$96.7 \pm 1.0$ $+0.72 \%$ threonine

II. Fasted rats ${ }^{8}$

Intubation $^{1}$
8. Distilled water
9. Tryptophan ${ }^{3}$
10. Tryptophan ${ }^{3}+$ glucose $^{4}$
11. Methionine ${ }^{5}+$ threonine $^{6}$
Feeding $^{7}$
12. $\mathrm{PF}$
13. $\mathrm{PF}+1.2 \%$ tryptophan
14. $\mathrm{PF}+0.9 \%$ methionine $+0.72 \%$ threonine

\begin{abstract}
$95.5 \pm 1.3^{2}$
$96.2 \pm 1.2$

$94.1 \pm 1.5$

$94.1 \pm 2.1$
\end{abstract}

$3.31 \pm 0.08$
$3.46 \pm 0.17$
$3.26 \pm 0.08$
$3.12 \pm 0.08$
$3.73 \pm 0.04$
$3.81 \pm 0.03$
$3.98 \pm 0.04$

$37.5 \pm 0.2^{\mathrm{b}}$

$34.4 \pm 0.6^{\mathrm{c}}$

$34.4 \pm 0.1^{\mathrm{c}}$

$33.5 \pm 0.3^{\mathrm{cd}}$

$41.1 \pm 0.4^{\mathrm{a}}$

$41.2+0.2^{\mathrm{a}}$

$37.5 \pm 0.3^{\mathrm{b}}$

1 Rats were sacrificed 1 hour after tube-feeding.

2 Means \pm S.E.M. of three or four rats per group. Means within a column not followed by the same superscript letter are significantly different $(p<0.05)$.

$30.15 \mathrm{mmol}$ L-tryptophan per $100 \mathrm{~g}$ body weight.

$4 \quad 2.3 \mathrm{~g}$ glucose per $100 \mathrm{~g}$ body weight.

$5 \quad 0.15 \mathrm{mmol} \mathrm{L}$-methionine per $100 \mathrm{~g}$ body weight.

$60.15 \mathrm{mmol} \mathrm{L}$-threonine per $100 \mathrm{~g}$ body weight.

7 Rats were sacrificed 5 hours after meal-feeding.

843 hours fasted rats.

tryptophan (Table V). The contents of serum insulin of rats intubated with glucose were significantly increased and, in the case of further supplementation of tryptophan, the values were slightly decreased but were significantly higher than that of the control group intubated with water. The contents of serum glucocorticoid were significantly increased by the intubation of glucose and/or tryptophan.

Effects of some amino acids on hepatic polysome profiles and serum glucocorticoid in starved rats (experiment 7)

In the case of tryptophan intubation to 48 hours-fasted rats, hepatic ribosomes were significantly aggregated as compared with those in rats intubated with methionine, threonine or leucine (Table VI). While, when rats previously injected with insulin were further intubated with tryptophan, all rats grew weaker and two to three rats died within two hours after intubation of tryptophan. In the case of previous injection of insulin, tryptophan intubation caused the aggregation of hepatic ribosomes as compared with in rats intubated with water (group 6). Moreover, the monomer-dimer values per total ribosomes of rats previously injected with insulin and in- 


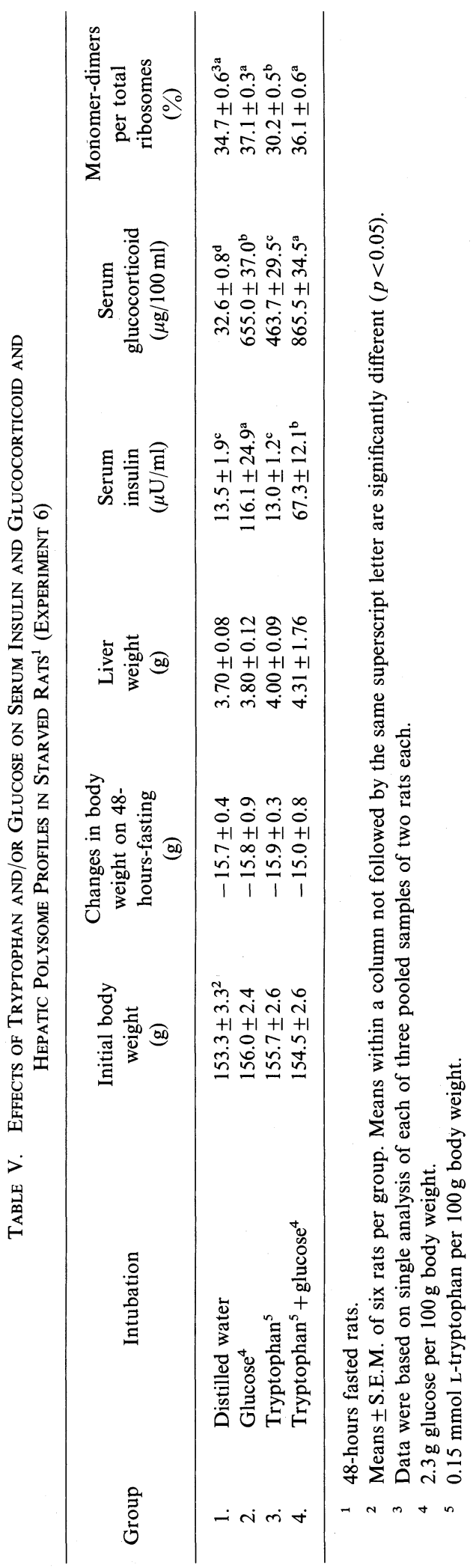




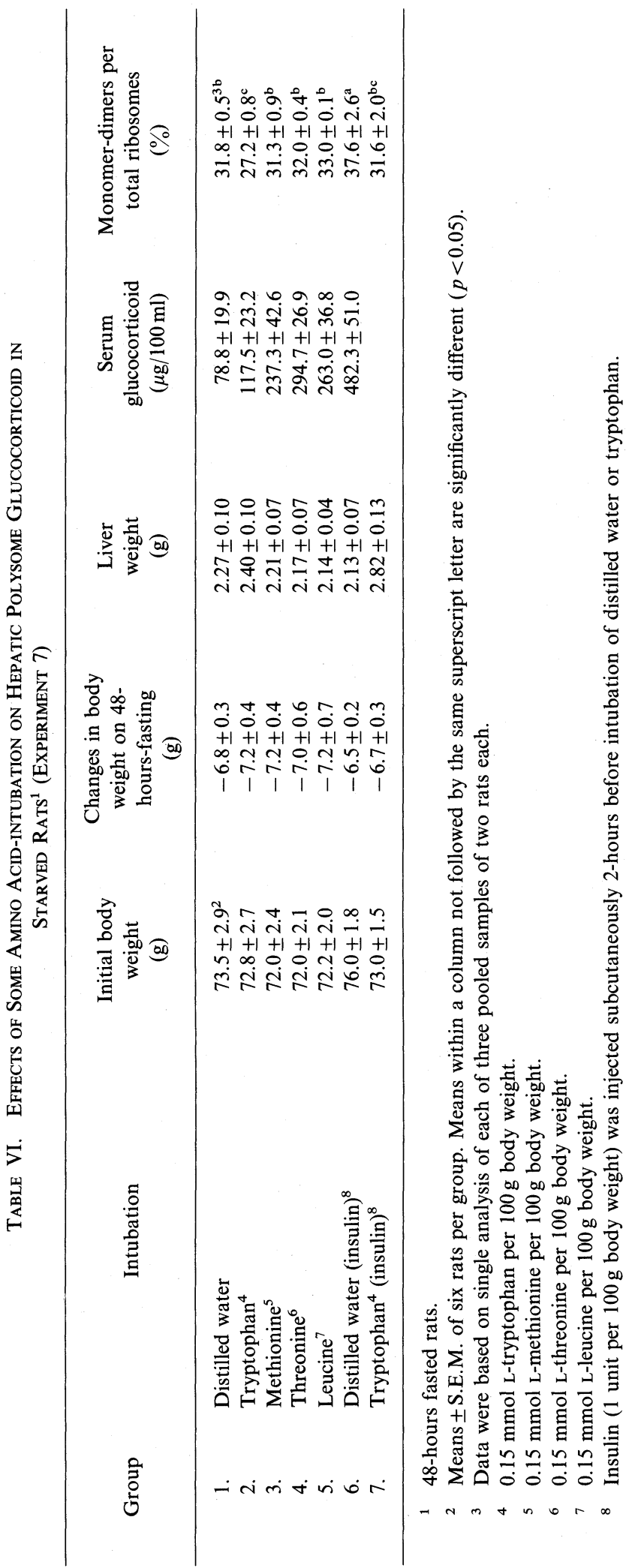


tubated with water (group 6) were significantly disaggregated as compared with those of rats intubated with water (group 1). The contents of serum glucocorticoid in rats intubated with each amino acid or insulin were significantly increased as compared with those of rats intubated with only water.

\section{DISCUSSION}

It was reported that the administration of tryptophan to fasted mice or rats caused increases in polyribosomal aggregation and protein synthesis (in vivo and in vitro). ${ }^{6 \sim 13)}$ It is considered that tryptophan is concerned in the specific action for protein synthesis in the body. However, in our previous experiment, ${ }^{14)}$ aggregation of hepatic ribosomes of rats mealfed the protein-free diet supplemented with tryptophan was not observed as compared with that of rats meal-fed the protein-free diet. In this work, we reinvestigated the effect of feeding or intubation of tryptophan or both methionine and threonine on hepatic polysome profiles. At first in meal-feeding conditions, the supplementary tryptophan to the protein-free diet did not cause the aggregation of hepatic ribosomes (Tables I and II). However, extensive observations have been made regarding the effect of tryptophan intubation on hepatic protein synthesis and on polysomal aggregation in fasted mice or rats. $^{6 \sim 13)}$ Then, in the slight fasting conditions, the effect of feeding or intubation of tryptophan or methionine and threonine on hepatic polysome profiles was investigated. Intubation of tryptophan or methionine and threonine caused the aggregation of hepatic ribosomes (Tables III and IV). This effect of tryptophan administration on polysomal function agreed with other reports, ${ }^{6 \sim 13)}$ on the other hand, the effect of supplementation of methionine and threonine on this aggregation was a new observation. However, in the fasting conditions, the supplementation of tryptophan or both methionine and threonine to the protein-free diet did not cause the aggregation of hepatic ribosomes. In our pre- vious work, ${ }^{14)}$ when rats were fed ad libitum or meal-fed the protein-free diet supplemented with methionine and threonine, the ribosomes in liver were significantly aggregated as compared with those of rats fed the protein-free diet. Then, the effect of the difference of fasting time and glucose (as the protein-free diet contained more sucrose as a carbohydrate source) on polysomal function was further examined. When tryptophan or tryptophan and glucose or methionine and threonine were intubated to the slightly starved rats trained for the mealfeeding schedule, the ribosomes were slightly aggregated. However, the tryptophan supplemented to the protein-free diet did not cause the aggregation of hepatic ribosomes (Table IV). Therefore, it was considered that, in the meal-feeding conditions (this means slight fasting), tryptophan was not limited and methionine and threonine might be rather limited in liver. This observation agreed with our previous experiments in which methionine and threonine were seen to be the first limiting amino acids under protein-free conditions. ${ }^{14)}$ On the other hand, in the long-term fasting conditions, the intubation of only tryptophan caused significant aggregation of hepatic ribosomes and the supplementation of both tryptophan and glucose did not affect the polysomal aggregation as compared with in rats intubated with water (Table IV). The supplementation of tryptophan or both methionine and threonine to the protein-free diet also did not cause the aggregation of hepatic ribosomes. Therefore, it has been speculated that, in the long-fasting conditions, though Wittman reported ${ }^{19)}$ that hepatic tryptophan levels in fasted rats were not decreased but actually were increased, tryptophan might be most limited for protein synthesis in liver and both methionine and threonine were not so limited. While, the inhibition by glucose and a protein-free diet of polysomal aggregation caused by tryptophan was not known. Then we determined serum insulin and glucocorticoid in the long-term fasting conditions. Glucose intubation caused significant enhancement of serum insulin but, on further 
intubation of tryptophan, this increase of serum insulin caused by glucose was reduced (Table V). Serum glucocorticoid was dramatically increased by the administration of glucose and/or tryptophan. However, the hepatic ribosomes were significantly aggregated on only tryptophan intubation. Therefore, in the case of the intubation of tryptophan, it was suggested that free amino acids caused by the enhanced breakdown of extrahepatic tissue proteins due to glucocorticoid action, especially in muscle, entered the liver and, as tryptophan which might be low in liver was supplied by stomach tube, hepatic ribosomes were significantly aggregated. Because it was known that glucocorticoid acts to increase the degradation of muscle proteins ${ }^{20 \sim 22)}$ such as enhancement of myofibrillar protease or amino acid incorporation in liver proteins. In our experiments, glucocorticoid might have acted on the polysome aggregation in liver due to the enhanced degradation of muscle proteins but this aggregation due to tryptophan cannot be explained by only the glucocorticoid action. Though tryptophan or other amino acids enhanced the serum glucocorticoid, hepatic ribosome aggregation was not observed except with tryptophan (Table VI). Therefore, the action of tryptophan might be contained in a specific action for protein synthesis such as the glucocorticoid action as suggested by Cammarano $^{23)}$ and other factors such as the substrate for protein synthesis. On the other hand, it was suggested that insulin acts to increase muscle protein synthesis. ${ }^{24 \sim 33)}$ As insulin was significantly enhanced on the addition of glucose in our experiments, the systems of protein synthesis in muscle might be fully prepared but the substrates for protein synthesis such as amino acids might be limited or enter the muscle from the liver. Therefore, it might be considered that, when rats were previously injected with insulin, the hepatic ribosomes might be more disaggregated (group 6, Table VI) than those of control rats (group 1, Table VI). However, Wittman et al. ${ }^{19)}$ reported that glucose refeeding restored the hepatic polysome profiles of 60 hours fasted rats and insulin administration also restored the polysomes of an alloxan-diabetic rat within 1 hour. These differences between the glucose effect and polysome functions in liver must be further investigated.

\section{REFERENCES}

1) W. H. Wunner, J. Bell and H. N. Munro, Biochem. $J .$, 101, 417 (1966).

2) A. W. Pronczuk, B. S. Baliga, J. W. Triant and H. N. Munro, Biochim. Biophys. Acta, 157, 204 (1968).

3) H. Sidransky, M. Bongiorno, D. S. R. Sarma and E. Verney, Biochem. Biophys. Res. Commun., 27, 242 (1967).

4) H. Sidransky and E. Verney, Proc. Soc. Exp. Biol. Med., 135, 618 (1970).

5) B. Pamart, A. Girard-Globa and G. Bourdel, $J$. Nutr., 104, 1149 (1974).

6) H. Sidransky, E. Verney and D. S. R. Sarma, Am. J. Clin. Nutr., 24, 779 (1971).

7) H. Sidransky, D. S. R. Sarma, M. Bongiorno and E. Verney, J. Biol. Chem., 243, 1123 (1968).

8) D. S. R. Sarma, E. Verney, M. Bongiorno and H. Sidransky, Nutr. Rep. Int., 4, 1 (1971).

9) C. N. Murty, E. Verney and H. Sidransky, Lab. Invest., 34, 77 (1976).

10) C. N. Murty, E. Verney and H. Sidransky, Biochim. Biophys. Acta, 474, 117 (1977).

11) C. N. Murty, E. Verney and H. Sidransky, Biochem. Med., 22, 98 (1980).

12) E. Verney and H. Sidransky, Proc. Soc. Exp. Biol. Med., 158, 245 (1978).

13) O. J. Park, L. M. Henderson and P. B. Swan, Proc. Soc. Exp. Biol. Med., 142, 1023 (1973).

14) H. Yokogoshi and A. Yoshida, J. Nutr., 110, 375 (1980).

15) A. E. Harper, J. Nutr., 68, 405 (1959).

16) H. Yokogoshi and A. Yoshida, J. Nutr., 109, 148 (1979)

17) A. E. Kitabchi and L. C. Kitchell, Anal. Biochem., 34, 529 (1970).

18) D. B. Duncan, Biometrics, 13, 164 (1957)

19) J. S. Wittman III, Kai-Lin Lee and O. N. Miller, Biochim. Biophys. Acta, 174, 536 (1969).

20) F. T. Kenney, D. L. Greenman, W. D. Wicks and W. L. Albritton, "Advances in Enzyme Regulation," Vol. III, ed. by G. Weber, Pergamon Press, New York, 1964, pp. 1 10.

21) M. Mayer, E. Shafrir, N. Kaiser, R. J. Milholland and F. Rosen, Metabolism, 25, 157 (1976).

22) A. Korner, J. Endocrin., 21, 177 (1960).

23) P. Cammarano, G. Chinali, S. Gaetani and M. A Spadoni, Biochim. Biophys. Acta, 155, 302 (1968).

24) I. G. Wool and P. Cavicchi, Biochem., 6, 1231 (1967).

25) I. G. Wool and M. E. Krahl, Am. J. Physiol., 196, 
961 (1959).

26) K. L. Manchester and F. G. Young, Biochem. J., 70, 353 (1958).

27) V. R. Young, G. Vilaire, P. M. Newberne and R. B. Wilson, J. Nutr., 103, 720 (1973).

28) D. J. Millward, D. O. Nnanyelugo, W. P. T. James and P. J. Garlick, Br. J. Nutr., 32, 127 (1974).

29) V. M. Pain and P. J. Garlick, J. Biol. Chem., 249, 4510 (1974).

30) R. M. Fulks, J. B. Li and A. L. Goldberg, J. Biol.
Chem., 250, 290 (1975).

31) G. E. Mortimore and A. N. Neely, "Intracellular Protein Turnover," ed. by R. T. Schimke and N. Katunuma, Academic Press, New York, 1975, pp. $265 \sim 279$.

32) J. S. Wittman III and O. N. Miller, Am. J. Clin. Nutr., 24, 770 (1971).

33) K. Nakano and H. Sidransky, J. Nutr., 108, 399 (1978). 